\title{
Rottnest Island: Cultural Landscape as a Means of Reconciliation
}

\author{
Jane L. Lennon \\ Jane Lennon and Associates, Heritage Consultants. Hon Professor, Faculty of Architecture, Building \\ and Planning, University of Melbourne. Adjunct professor, Centre for Cultural Heritage of Asia and \\ Pacific, Deakin University, Melbourne. \\ jlennon@hotkey.net.au
}

Publication Information:

Received 22 August 2016, Accepted 27 June 2017, Available online 28 June 2017

doi: 10.21463/jmic.2017.06.1.03

\section{Abstract}

Rottnest Island/Wadjemup is an important cultural landscape where human interaction with natural systems over time has formed a distinctive landscape. It has high degree of heritage significance to the people of Western Australia. Its heritage values include: an exceptional combination of geological and ecological features and processes; significant cultural value for Aboriginal people as its intangible heritage is associated with Dreamtime stories concerning death and the creation of the offshore islands; archaeological evidence of human occupation of the Island prior to its separation from the mainland, possibly dating to 30,000 years ago; a key site in early exploration of Australia by Dutch mariners who landed on the Island and surveyed the coastline in the 17th century; a remarkably intact British colonial outpost and penal establishment dating from the early to mid-nineteenth century; a rare purpose-built Aboriginal prison; shipwrecks around the Island's seascape and lighthouses on the Island; a key site for Australia's coastal defence during World War II. Transition to a place of recreation is a tangible illustration of the importance of islands to mainlanders, particularly in providing a strong sense of place. Visible from the metropolitan coastline, the Island has outstanding aesthetic qualities that continue to capture the imagination. Because of its significant history, including its place as what is believed to be the largest Aboriginal deaths in custody site in Australia, and one of the largest Aboriginal burial grounds in the State, the Island has the potential to become an important focal point for reconciliation and healing between Aboriginal and nonAboriginal people. This paper will show how using the concept of a cultural landscape, the management authority is implementing an integrated planning system for the Island which will assist in respecting all heritage values but acknowledge the previously hidden Indigenous beliefs and painful Aboriginal history of incarceration.

\section{Keywords}

Cultural landscape, heritage management, Aboriginal history, reconciliation 


\section{Introduction}

Islands have different qualities from other land masses: they admit sovereignty of sea and sky; they tend to turn their inhabitants inwards breeding stoicism and self reliance. They commonly harbour both castaways and conquerors. Islands serve as prime sites of imagination as self-contained miniature worlds, mocking or inverting the existing social order as in More's Utopia and Shakespeare's Tempest. Fictional islands continue to be preferred locales of both despair and ecstasy while utopian and dystopian ways of life are often transplanted from isles of fancy to actual islands as with the Pitcainers move to Norfolk Island in the mid-nineteenth century. Antithetical stereotypes of paradisiacal sea, sun, sand and sex (Gaugin, Robert Louis Stevenson, South Pacific) and of poverty, misery and abandonment (Easter Island, St Kilda, Nauru) dominate island literature, now as millionaire's haunts (Capri, Mustique, Whitsundays), now as dead-end dumps or refugee containments (Pitcairn, Nauru, Manus) (Lowenthal, 2003:3). Being isolated, remote and circumscribed by water often puts islands at risk, just as limited size and resources leave their inhabitants little margin for error. Australians occupying a whole island continent though vast in size [7.6 million hectares with $47,000 \mathrm{~km}$ of coastline] know this in relation to their water resources. As the world's largest island, Australia is surrounded by thousands of smaller islands. But isolation, remoteness, enclosure and containment also make islands ideal prisons (Lennon, 2009). Hence the archipelago of island convict prisons dotted on the coastline of the continent of Australia, itself a larger island at 'the ends of the earth' from the mother country, England; or the Devil's Island of French Guiana, Ducos peninsula on New Caledonia, Napoleon's St Helena, Mandela's South African Robben Island and many more.

Islands of banishment might evolve into islands of vanishment but for the efforts of heritage conservation retaining the history and social values of previous inhabitants and their descendants. This paper traces such a story for an island offshore from the main island of Australia.

Rottnest Island/Wadjemup is an important cultural landscape where human interaction with the natural systems over time has formed a distinctive landscape. The Nyungar (also spelt Noongar, Nyoongar, Nyungah) name of the Island is Wadjemup, which has been interpreted to mean 'the place across the water where the spirits are'. While pre-colonial European maps record the Dutch name of 'Rottenest' and later the anglicised 'Rottnest', Wadjemup has not only been held in the long term cultural memory of the Nyungar people, it has been recorded as such on maps of the Island since the first colonial contact with the Aboriginal people of south-western Australia. Rottnest Island lies in the Indian Ocean west of the metropolitan coastline of Perth and approximately 20 kilometres from the port city of Fremantle in Western Australia. The Island (latitude $32^{\circ} 00 \mathrm{~S}$, longitude $115^{\circ} 30 \mathrm{E}$ ) is $11 \mathrm{~km}$ long and $4.5 \mathrm{~km}$ at its widest point, lying roughly perpendicular to the mainland. The land area of 1,900 hectares and associated seascape are included in the A-class reserve. Rottnest Island/Wadjemup is managed in accordance with the Rottnest Island Authority Act 1987. The Minister for Tourism is responsible for administering the Act on behalf of the Western Australian Government. 


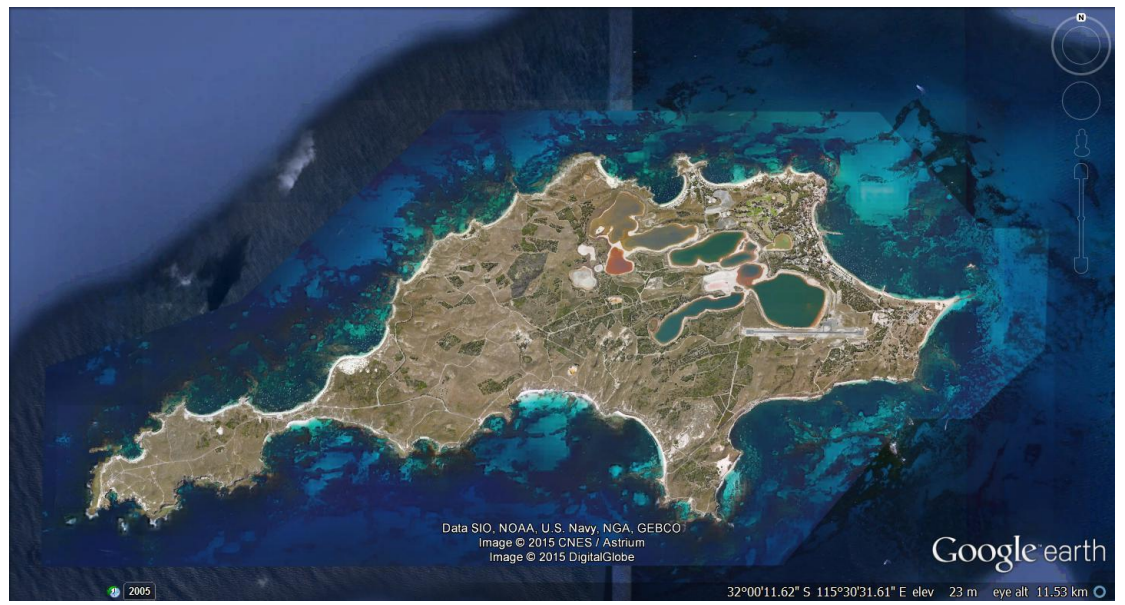

Fig 1. Location: Rottnest Island (Google image, 2015)

\section{Heritage Values}

Under Australia's tiered system of heritage recognition, Rottnest has been listed by both State and Commonwealth authorities. The Western Australian listing is at Heritage Place no. 3650 - Rottnest Island/ Wadjemup, [http://inherit.stateheritage.wa.gov.au/Public/p/3650] while the Commonwealth listing on the Register of the National Estate ceased to have statutory power in 2007.

The statement of cultural significance for the Rottnest Island cultural landscape (RICLMP, 2015:72) has identified the following 11 heritage values:

- It has an exceptional combination of geological and ecological features and processes, many of which are of international importance in the study of sea level and climate variations associated with the late Pleistocene and Holocene times.

- It has significant cultural value for Aboriginal people, being associated with a number of Dreamtime stories concerning death and the creation of the offshore islands. There is also archaeological evidence of human occupation of the island prior to its separation from the mainland, possibly dating as far back as 30,000 years.

- It is a key site in the early exploration and the beginning of an understanding of what became known as the Australian continent by European mariners, commencing with the Dutch mariners who landed on the Island and surveyed the coastline in the 17th century.

- It is rare as a purpose-built Aboriginal prison, believed to be the only one of its kind in Australia. This penal establishment played a seminal role in the history of the development of the Swan River Colony and the State of Western Australia and is significant for its role in the removal, punishment and enforced labour of Aboriginal men and boys during the immediate Contact and post-Contact periods.

- It has recognised archaeological potential to widen the understanding of Aboriginal occupation prior to the separation of the Island from the mainland and the life and traditions of both Aboriginal and non-Aboriginal people in the post-colonial era. 
- The colonial settlement on Rottnest Island/Wadjemup remains a remarkably intact example of a British colonial outpost and penal establishment dating from the early to mid-nineteenth century, which continues to impart its influence into the present day.

- The shipwrecks around the Island's seascape and the maritime infrastructure on the Island demonstrate not only the dangers of the maritime journeys that were an essential part of the colonial development of Australia for over a hundred years, but the vital role that the ships have played in the lives of Western Australians since the founding of the Swan River Colony.

- It is recognised for its strategic importance as a key site for Australia's coastal defence during World War II. The military infrastructure from this time demonstrates the high level of technical achievements and the role of the Australian men and women in the defence of Australia during World War II. It is distinguished nationally as the only place to have retained the 9.2 inch guns in its batteries.

- The transition of the Island to a place of recreation and respite provides a tangible example of the importance of islands to mainlanders, particularly in providing a strong sense of place. It embodies the quintessential Australian holiday experience of the twentieth century that was neighbourly, practical and democratic. The relaxed atmosphere and safe friendly environment combined with a sense of wildness and connection to both nature and history contribute to the strong community attachment to the Island.

- A constant, yet ever changing vision on the horizon from the metropolitan coastline, it has outstanding aesthetic qualities that continue to capture the imagination. The settlement area characterised by a sweeping bay and marked by the sea wall, distinctive limestone colonial buildings and avenues of tree plantings contributes to a strong sense of place, while the sublime coastal scenery of embayment, beaches and limestone cliffs with rolling dunes behind is enhanced by the spectacular natural phenomenon of the salt lakes, evocative lighthouses and the subtle colours of the natural geology and vegetation.

- Because of its unique and significant history, including its place as what is believed to be the largest Aboriginal deaths in custody site in Australia, and one of the largest Aboriginal burial grounds in the State, the Island has the potential to become one of the most important focal points for reconciliation and healing between Aboriginal and non-Aboriginal people in Western Australia and potentially the nation.

This diverse group of values has been studied and many sites on the Island have been listed as separate entries in the Western Australian Register of Heritage Places, Shipwrecks Register and Register of Aboriginal Sites. Many plans for their protection have been prepared but the Rottnest Island Authority decided in 2013 to prepare a cultural landscape management plan to embrace all these values exhibited in the landscape, both the tangible and intangible heritage. The preparation of the Plan has been informed by the methodology and principles outlined in the following documents:

- The Australia ICOMOS Burra Charter and Guidelines (2013)

- Standard Brief for Conservation Management Plans, State Heritage Office of Western Australia

- Guidelines for the Assessment of Places for the National Heritage List, Australian Heritage Council (2009)

- World Heritage Cultural Landscapes: A Handbook for Conservation and Management, UNESCO World Heritage Centre (2009).

The Cultural Landscape Management Plan provides a narrative that interweaves the oral, documentary and physical evidence to provide an overview of the interaction of the environment and people over many thousands of years which has created the cultural landscape experienced today. It assessed the values of the Island as a whole and determined the rarity and representativeness of those values through both national and international comparative studies, as well as 
an assessment of the condition of those values. These assessments of significance, condition and need for conservation works resulted in overarching principles and conservation policies for the management of Rottnest Island/Wadjemup as a highly significant cultural landscape.

\section{The Formation of Rottnest Island/Wadjemup}

Rottnest Island/Wadjemup is the largest island in a chain of islands and shoals on the continental shelf near Perth. It is composed of marine and dune limestone and sand formed during Pleistocene and Holocene periods and formed part of the mainland until a series of sea level changes took place from the Late Pleistocene resulting in today's Island (Playford, 1997). Elevated marine features, which indicate sea level changes, include the fossil coral reef at Fairbridge Bluff and Mount Herschell Quarry where marine shell beds of Herschell Limestone are exposed. Some excellent examples of wave-cut platforms and notches are found around the edges of the salt lakes where they are not prone to coastal erosion. These features, together with fossil evidence and topographic evidence, are of international importance in the study of sea level and climate variations associated with the Pleistocene ice age (RNE, ID 18825, 2014).

\section{Flora and Fauna}

Prior to separation from the mainland, Rottnest Island/Wadjemup would have had a similar range of plants as those on the adjacent mainland where about 1,500 native species flourish. Exposure to sea water, salt and wind eliminated hundreds of species so that today there are only about 140 indigenous species left on the Island. Cultural activities from the colonial and post-colonial eras have altered and, in places, degraded the natural environment. Today approximately $4 \%$ of the Island is covered by scattered relic stands of woodland comprising Rottnest Island Pine (Callitris preissii) and Rottnest Island Tea Tree (Melaleuca lanceolata) which is listed as a 'Vulnerable' Threatened Ecological Community under the Wildlife Conservation Act 1950. The quokka (Setonix brachyurus) is the most well-known animal on the Island and is listed as 'Vulnerable' under State and Commonwealth legislation, and 'Vulnerable' on the global IUCN Redlist. A marsupial the size of a hare or domestic cat, the quokka is the sole representative of the genus Setonix (RICLMP: 12).

Approximately 400 species of fish and twenty species of coral occur within the Marine Reserve. The coral at Pocillopora Reef, Parker Point, is considered the southern- most tropical coral reef in Australia (RNE ID 18837, 1997).

\section{Early Aboriginal Occupation and Cultural Narrative}

Various colonial authors recorded Nyungar cultural narratives about the creation of the offshore islands and coastline features. A story recorded in 1836 attributes their creation to the actions of the Waugal or Rainbow Serpent. Another story in 1884 describes a great fire which caused the ground to split and the sea to rush in, cutting off the islands from the mainland. This story has been interpreted as an expression through cultural memory of the sea level rise that 
occurred around 6,500 years ago, and versions are also recorded in Bates (1992) and Ker Wilson (1979). Wadjemup is also associated with Nyungar beliefs concerning death and the Island is variously interpreted as a stop on the way to Kooranup (the home of the dead) or as being part of Kooranup. (RICLMP: 9). Offshore islands around southern Australia across to Tasmania have archaeological evidence of and ethnographic status as uninhabited 'islands of the dead' for adjacent mainland Aboriginal groups (Draper, 2015). As archaeological survey has shown, the existing record of early human presence on Wadjemup is 'sparse in the extreme' (Dortch 2013:19).

\section{European Exploration}

\section{Dutch Exploration}

Until the early 1600 s, Europeans had only a vague notion of what is now called Australia. Following the first authenticated European sighting of the Australian coastline in the Gulf of Carpenteria by Willem Janszoon on the Duyfken in 1606, Dutch exploration and surveying then occurred along the Western Australian coastline with Rottnest Island/Wadjemup playing a key part in the European understanding of the Australian continent. The first sighting of Rottnest Island/Wadjemup was by Frederick de Houtman in 1619. In 1658 men from the Waeckende Boey searching for survivors of an earlier shipwreck went onshore at the northeast of the Island and reported that it was well wooded, but they could find no easy anchorage due to the cliffs close to shore. Seals and a 'bush cat' were sighted (Gerritsen, 2011, p14). In 1697 Willem de Vlamingh careened at what is now Thomson Bay to explore and named the Island 'Rotte nest', meaning 'rat's nest', which is understood to refer to the marsupial quokkas, which abound on the Island. The name remains in use today.

\section{French Explorers}

During the late 1700 s and early 1800 s, the French played a significant role in the European discovery and charting of the mysterious land mass then known as New Holland; they documented its flora, fauna and human inhabitants. In 1801, Napoleon supported Nicolas Baudin's expedition which added immeasurably to the sum of scientific and cartographic knowledge of the 'Terres Australes'. The expedition started off with two ships Géographe, captained by Baudin, and Naturaliste captained by Jacques Hamelin. Rottnest Island/Wadjemup was a rendezvous point when the two ships became separated in a storm and the Naturaliste spent two weeks anchored off Rottnest Island/Wadjemup in June 1801. Following this expedition, Louis de Freycinet, who was aboard the Naturaliste, published the first map of Australia in 1805. His surveys of both Thomson Bay and the salt lakes on Rottnest Island/Wadjemup survive from this expedition.

\section{British Exploration}

In the late 1700 s sealers associated with the British colonial settlements of the eastern seaboard of Australia are reported to have made their way west from the southern Australian coast as far north as Rottnest Island/Wadjemup. However, war between the French Empire and opposing coalitions led by the British, which occurred intermittently 
between 1803 and 1815, largely halted exploration of the western coast of Australia by Europeans. The next explorer to visit the Island was the first Australian born maritime explorer, Philip Parker King in 1822. He, like the French and Dutch before him, was unimpressed by the area for potential settlement. However, in 1827 Captain James Stirling explored the Swan River area in HMS Success, which first anchored off Rottnest Island/Wadjemup. Swan River Colony was proclaimed for Britain on 2 May 1829.

\section{Colonial Settlement}

British settlers soon established themselves on the Island attracted by the prospects of salt harvesting, farming and fishing. In December 1830, Benjamin Smythe surveyed the Island and a plan for the township to be known as Kingstown around Thomson Bay was designed, containing 177 lots of one third of an acre and other lots of 10 acres to be offered to the public. By 1838 , the farmers were grazing sheep and had established crops, vegetable gardens and vineyards. All this changed in August 1838 when six Aboriginal prisoners were brought to the Island. After a short period when settlers and prisoners coexisted on the Island, the Colonial Secretary announced in June 1839 that Rottnest Island/Wadjemup would become a penal establishment for Aborigines. This formally came into existence with the 1841 Act to Constitute the Island of Rottnest as a Legal Prison. The Crown resumed all land and restricted access to the Island, compensating settlers with property on the mainland (RICLMP: 19).

\section{Colonial Penal Establishment for Aboriginal Prisoners}

Historians have identified three phases in the history of the Island as an Aboriginal prison: The first, $1838-49$, might be regarded as a humanitarian period when the intention was not merely to punish but also to rehabilitate the prisoners into colonial society. The second stage, 1855-1902, was a grim period when more than 3,000 prisoners arrived on the Island. In the final stage, 1902-31, Rottnest Island became an annex of Fremantle Prison (Green and Moon 1997:14). Aboriginal prisoners were to have the limited freedom of the Island and, after Superintendent Vincent's administration, this was the case on Sundays when they were allowed to roam, hunt and fish, and were permitted to perform corroborrees. As prisoners, they were set to work erecting many of the buildings and other structures that still survive on the Island, including the seawall and lighthouses, and making the penal establishment a self-sustaining enterprise through cultivating the land, gathering wood, catching fish and collecting salt from the lakes. Vincent was a veteran of the peninsular wars and designed the buildings in military style with a distinctive Spanish effect (Sheiner, 1986:130). Most tasks, particularly the building and agricultural activities, were completely foreign to Aboriginal cultural practices. However, Rottnest Island/Wadjemup was a penal establishment designed from the start to be a deterrent to the Aborigines against committing what the Protector of Natives, Charles Symmons, described as 'acts of aggression' against the settlers. The natives lived in fear of Rottnest and the brutal Henry Vincent, who served as Superintendent from 1839-49 and again from 1855-67, made the prisoners' lives miserable. The new prison, known as the Quod, was completed in 1864-65 and was designed to accommodate 150 prisoners (Watson 1939, p.32), but by 1883 there were 167 prisoners crammed into the cells and more than 60 died in the winter of that year from influenza (Green and Moon 
1997:24-25). By far the most common offence to 1884 was stock killing (Green 2011:79). For tens of thousands of years, Aboriginal people had survived by hunting the animals that roamed their traditional lands, such as kangaroos, bush turkeys, goannas and so on. Killing sheep or cattle, the new species of game which suddenly appeared throughout their familiar landscapes, led to men being taken away for doing something that was part of daily life and increasingly necessary as traditional resources were depleted or became less accessible as a result of colonisation and pastoralism.

They were removed for breaching British laws which they did not understand, and then charged and sentenced by men of a race they had never seen before, speaking a strange language they could not comprehend. They were marched in chains to gaols such as Roebourne and from there taken by boat (an alien mode of transport) to Rottnest Island/Wadjemup which was outside their traditional territory to be housed alongside other men from different territories with different languages and traditional laws. Many of the sentences were found to be illegally harsh and lengthy and the result of 'an over-zealous prosecution of the law', with guilty pleas often secured 'at the muzzle of the rifle' (Green 2011:70-81). Their removal not only crippled active resistance to the invasion, it effectively destroyed established social structures and led to the gradual decline of traditional knowledge and culture across the State, all of which has had lasting ramifications for the Aboriginal people of Western Australia down to the present day. Their children became among the first generation to work on the vast pastoral stations that spread over their ancestral homelands.

\section{Deaths in Custody}

Between 1838, when the first prisoners arrived, and 1931 when the last prisoner left the Island, more than 3,700 Aboriginal men and boys from throughout the State were sent to Rottnest Island/Wadjemup. It is estimated that more than $10 \%$ of these men and boys died there (Green and Moon 1997:59), making Rottnest Island/Wadjemup the largest Aboriginal deaths in custody site in Australia and the Quod in particular the largest deaths in custody building in Australia. However, the actual number of Aboriginal people buried on the Island will probably never be known. Those who died are believed to mostly be buried in unmarked graves in the Aboriginal Burial Ground.

These graves lay forgotten until the 1960s. The controversy that surrounds the burial ground at Rottnest-probably the largest Aboriginal cemetery in Western Australia-continues to contaminate relations between Aboriginal and nonAboriginal people. Despite consultations over the past several decades, the burial ground is still without any memorial other than some basic signage.

\section{The Legacy of the Aboriginal Prison}

The Aboriginal prisoners provided most of the manpower that sourced the raw materials for and built the main buildings, structures, sea wall and road infrastructure on the Island, many of which survive and are still used today. Many of these constructed during the 1840s and 1850s are some of the earliest colonial buildings in Western Australia. Aboriginal men and boys also worked the salt works, which was a thriving industry, undertook other labour that was needed to make the establishment viable including the telegraph installations, and in 1892 cleared all the existing roads across the Island as well as cutting a new road for a quarry to supply limestone for the light house construction. Rottnest Island/Wadjemup can be seen as a microcosm of the development of the State of Western Australia where Aboriginal manpower played an important, but often forgotten role (RICLMP:28). 


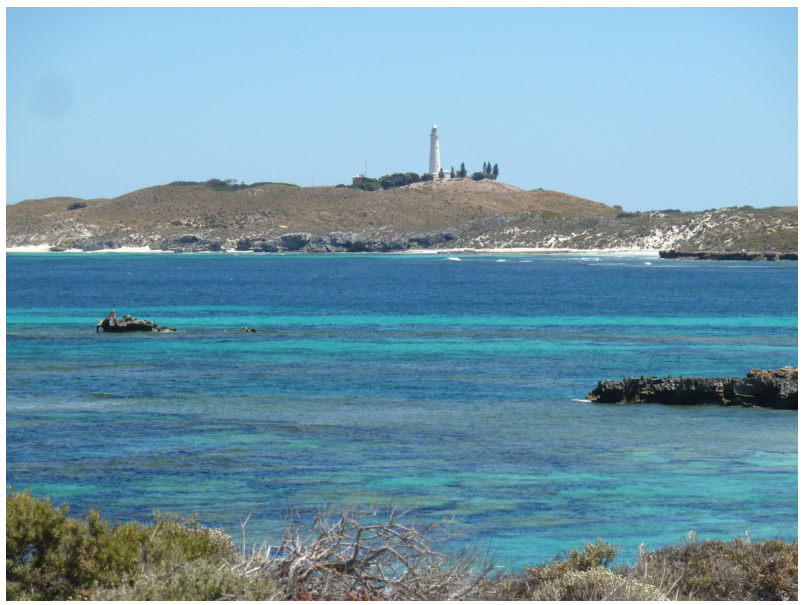

Fig 2. Lighthouse on Wadjemup Hill, Rottnest Island

The penal establishment on Rottnest Island/Wadjemup was a purpose-built Aboriginal prison-believed to be the only one of its kind in Australia-for almost half of the State's history, and yet it is a contested history that is almost entirely forgotten and/or ignored by the wider Western Australian community, for whom the Island is simply Perth's holiday playground. However, progress has been made and the Rottnest Island Authority acknowledges that: 'The pain suffered by Aboriginal people and the social disintegration that resulted from nearly 100 years of incarceration on the Island is still strongly felt by Aboriginal communities across the State today' (RIMP 2009-14:43). Wadjemup has timeless precolonial significance, and a significance arising from its more recent prison history. Contemporary Aboriginal people across the State continue to tell stories about their ancestors' experiences at the Aboriginal prison on the Island. Given its wretched post-contact history, many Aboriginal people find it almost impossible to reconcile the two faces of the Island, summed up in what filmmaker Glen Stasiuk has termed 'Wadjemup: Black Prison, White Playground'. They find it understandably difficult to come to terms with the fact that predominantly white tourists continue to relax and have fun apparently oblivious to that fact that in the not-too-distant past the ancestors of Aboriginal people were imprisoned, brutalised, suffered and died there. Because of its significant history, Rottnest Island/Wadjemup has the potential to become one of the most important focal points for reconciliation and healing between Aboriginal and non-Aboriginal people not just in Western Australia but for Australia as a nation. For this to occur, the pain and shame of the past needs to be acknowledged, and the untold history of the Island needs to be brought into the open in a much more conspicuous and inclusive way (RICLMP: 29). 


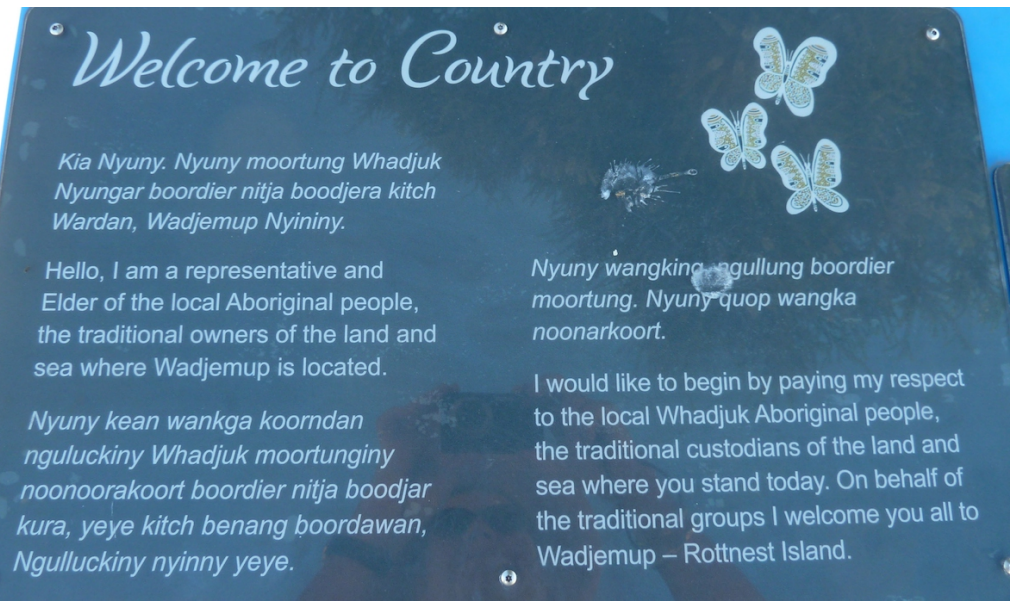

Fig 3. Welcome sign, Rottnest Island.

\section{Other Significant Heritage Values}

\section{Shipwrecks}

Rottnest Island/Wadjemup is surrounded by hidden and partly exposed reefs and can be buffeted by north westerly winter gales as well as very strong south westerly summer sea 'breezes'. As it is close to Western Australia's major port, Fremantle, much of the maritime traffic to passes close by. More than fourteen ships have been wrecked within the waters off the Island.

\section{Lighthouses}

Lighthouses played a key role providing a communication link between the pilot boat station and incoming ships. The Island's first lighthouse was completed in 1849 on Wadjemup Hill, with Aboriginal prisoner labour and locally quarried stone. Half a century later it was replaced with a new, taller lighthouse also on Wadjemup Hill; and a third was built in 1900 at Bathurst Point following the loss of 11 lives with the wreck of the City of York in 1899 (RICLMP: 39). 


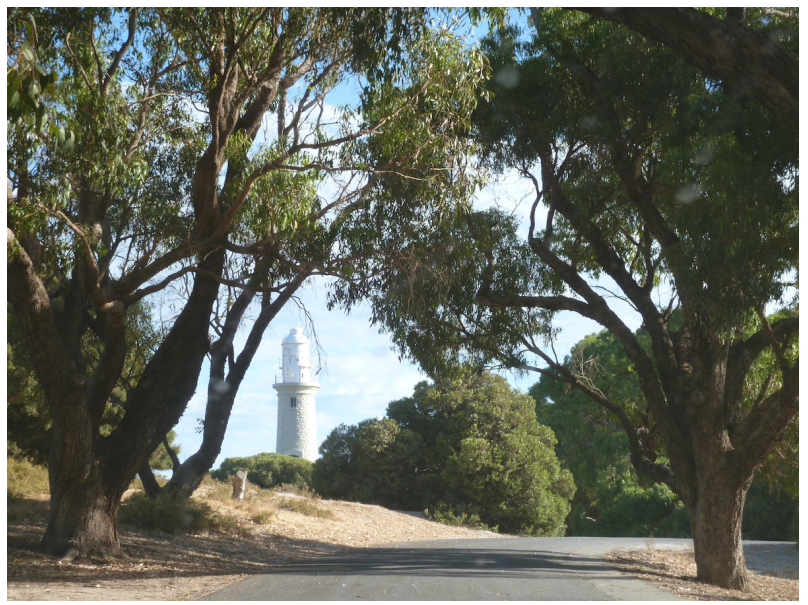

Fig 4. Lighthouse, Bathurst Point viewed from planted avenue, Thompson Bay settlement, Rottnest Island

For most travellers to Australia in the 19th and the first half of the 20th centuries, Rottnest Island/Wadjemup was the first sight of land and many anchored off the Island waiting to be piloted into Fremantle port. It was also the last sight of land for those who travelled back 'Home' (to Britain) or left for the wars in Africa, Europe and Asia on Navy ships.

\section{Governor's summer residence}

British Empire governors sought the most pleasant area available within their purview to retreat to from the summer heat found in the colonies. Governor Charles Fitzgerald in 1848 arranged for the construction of a summer residence on Rottnest which was occupied until 1913. Following the establishment of the Rottnest Island Board of Control in 1917, the Governor's Residence was converted to accommodation facilities for holidaymakers. In 1953 the building was converted into the licensed Rottnest Hotel.

\section{Australian Commonwealth Defence Establishments}

\section{First World War}

Western Australia obtained self-government in 1890 and in 1901 joined five other colonies to form a federation, which divided power between the six states and the government of the Commonwealth of Australia. The Commonwealth was given responsibility for a range of legislative areas, including naval and military defence as well as lighthouses and quarantine. With the outbreak of World War I, the Commonwealth Defence Department commandeered Rottnest Island/Wadjemup for use as an internment camp for the detention of enemy aliens, temporarily halting the fledging tourism on the Island. By early 1915, there were about 700 men of Serbian, Croatian and Dalmatian background housed in tents in the Rottnest Camp. Most had been employed as miners in the goldfields. The Defence Department handed the Island back to the State Government on 1 December 1915, along with $£ 2,000$ compensation for damages caused from the internment camp on the Island. This money was used to re-establish recreational and holiday facilities on the Island (RICLMP: 41). 


\section{Second World War}

During the 1930s as political tensions rose in Europe, the coastal defence of Australia was strengthened through the strategic placement of gun batteries around the Australian coastline, with the priority placement of 9.2 inch guns in Sydney Harbour and at Rottnest Island. The location of the Island was important to the defence of the deep water port of Fremantle, the major base for the Allies in the Indian Ocean. Major construction works commenced on Rottnest in 1935 to establish the Kingstown Barracks and the Bickley and Oliver Hill Batteries. In late 1942 the strength of the military on the Island peaked at 2,500, including personnel who operated the Port War Signal Station, as well as manning the radar station at Stark Bay and providing meteorological services for both gun batteries.

In 1967, when the Army returned most of its land holdings on the Island to the State Government, they retained the Kingstown Barracks and the Bickley area. In 1984 it was decided to use Barracks as the Kingstown Environmental Education Centre, catering for 250 people in dormitory or cottage-style accommodation.

\section{Public Park and Reserve}

From 1902, ferries carried tourists to Rottnest Island/Wadjemup on Sundays. During these times visitors and prisoners were kept well apart. In 1907 a scheme for transforming Rottnest Island/Wadjemup from a penal establishment to a recreation and holiday island was drawn up by the Colonial Secretary's Department. In 1917, Rottnest was made an A Class Reserve for public recreation and a Board of Control was established under the Parks and Reserves Act 1895, whereby no portion of the land could be leased or sold except by legislation, and the land resided with the Crown in perpetuity. During the 20th century Rottnest Island/ Wadjemup provided the widest choice of holiday accommodation in the State. In the inter-war years the Board provided a 'commodious' hostel for 200 people, furnished cottages, bungalows, flats and campsites. Prison buildings were adapted for holiday use, while canvas and timber structures, along with new timber bungalows, were built for families. The health benefits of a holiday on Rottnest were promoted in tourist marketing as 'Westeralia's Health Resort'. Along with fishing, swimming and boating, the curative properties of the salt lakes were also promoted (RICLMP: 46). By 1971 Thomson Bay Settlement contained 102 cottages, bungalows and flats, although not all visitors welcomed the extension of tourist development (Sheiner, 1986:133-4). Development continued at Longreach and Geordie Bays in 1978 -9 and all the accommodation specifically for tourism was constructed with a sea view. Generations of Western Australians have fond memories of holidays spent on Rottnest Island in the post-war years. In the 1950s families camped at chosen spots on the Island, which they returned to year after year, and for adults and children alike it was an unfettered playground (Seddon, 1983). With no private cars on the Island, bicycles were introduced and have remained a popular mode of transport around the Island. Rottnest Island/Wadjemup is a major tourism destination and its estimated value to the State's economy is over $\$ 100$ million per year. More than 500,000 people each year now visit Rottnest Island/Wadjemup, for both day-trips and overnight stays (RICLMP: 48). 


\section{Island Imaging}

\section{Landscaping and Planting}

The focus of land management on the Island during the colonial settlement period was on the construction of necessary infrastructure and productive activities such as growing food. The first olives to be exhibited internationally were grown by Henri Courderot in the 1880s, from two olive trees in the Settlement area. The first recorded major tree plantings were undertaken in the winters of 1886 and 1887, following the Forrest Commission's recommendation that pines should be planted to provide revenue. This resulted in approximately 1,000 pine trees of several species being planted at the northern end of the Settlement among the native woodland. The government nursery at Hamel supplied over 3,000 trees, including Aleppo Pines, Moreton Bay Figs, Peppermint Trees, Norfolk Island Hibiscus, poplars and wattles. Most were planted in 1907/08. During this time large areas of cleared ground were planted with trees, including at Bickley and at Bathurst Point, as well as an avenue of Moreton Bay Figs from the settlement to the old Governor's Residence and along the top of the sea wall. The Rottnest Island Authority is actively 'regreening' the Island. Planned restoration of the woodlands is occurring with Pine and Tea Tree seedlings being planted, as well as direct seeding of these and other species of plants native to Rottnest. Areas on the Island are selected, fenced against quokkas and then either planted or seeded in winter or allowed to regenerate naturally.

\section{Artistic Interpretations}

Aesthetic qualities continue to capture the imagination and the beauty of the cultural landscape of Rottnest has long held fascinated artists (Vizents, 2014; Snell, 1998). The Island is tantalizingly close to the mainland and has exerted a strong attraction to mainlanders because of its sense of place.

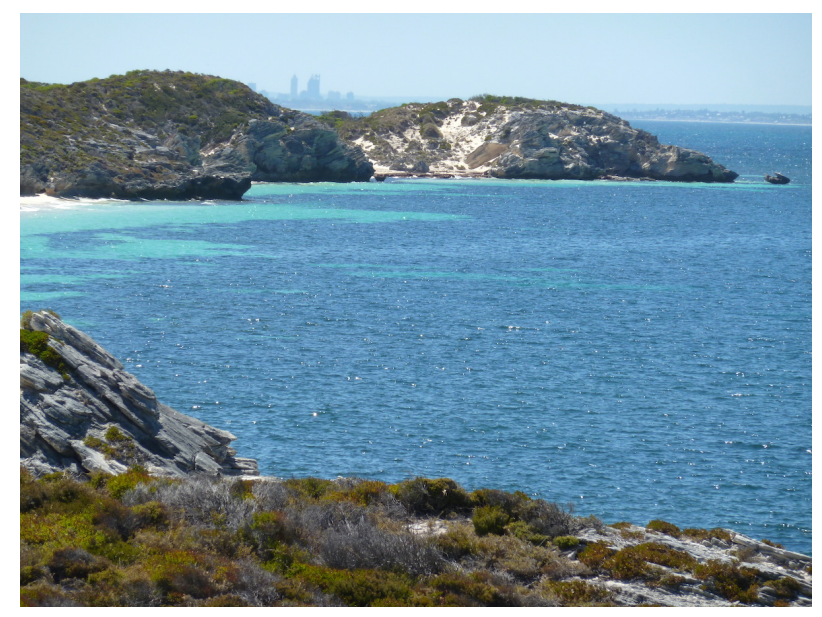

Fig 5. City of Perth skyline viewed from south east coast of Rottnest Island 
Today Rottnest has an artist-in-residence program and exhibitions of paintings by local and well-known artists. Writers and poets have also been inspired by Rottnest Island/Wadjemup and perhaps have been in a better position to convey the beauty as well as the sorrow of the Island. The shipwrecks have stirred the sympathy of many, while the misery of the prison and Aboriginal exile has been portrayed by others.

\section{Cultural Heritage and Reconciliation}

Despite the depictions and real life experiences of Rottnest as a holiday isle, it remains a place of mourning for many Aboriginal people and a tangible reminder of all that has been lost since colonisation. While the prison was closed over a hundred years ago and the Island opened to the public with an egalitarian sense of Australian mateship that extended to all classes, in practice this mateship did not extend to Aboriginal people. There are few stories of Aboriginal people holidaying on the Island and with the last of the prisoners not leaving until 1931 it is hardly surprising that many Aboriginal people view the Island with a sense of dread. Rottnest Island/Wadjemup has an important role to play in demonstrating the role of Aboriginal labour in the development of Western Australia. The prisoners built the main infrastructure on the Island, much of which is still used today. They also manned the salt works and undertook other labour that was needed to make the establishment viable. Most of these tasks were completely foreign to the cultural practices of the men and boys imprisoned on the Island and, while they remain a stark reminder of their enforced labour, they also stand as a particular testament to their skills and endeavours. Rottnest Island/Wadjemup has a potentially positive role to play in healing the sad past, while looking to a positive future for all Western Australians. The national apology issued by the Prime Minister of Australia in 2008 has helped this process and it is now the concern of every citizen to be aware of and care about treatment of the first Australians. While significant steps are being taken by the Rottnest Island Authority in terms of reconciliation, recognition of this painful past needs to be considered with reference to national and international examples of places where, increasingly, visitors are encouraged to understand the painful and often shameful past.

\section{Cultural landscape plan of management}

The Rottnest Island Authority believes is befitting the iconic island that the Rottnest/Wadjemup cultural landscape plan of management is the first plan to be underpinned by the UNESCO World Heritage Convention methodology for cultural landscapes in Western Australia. Under the Operational Guidelines (2008), Rottnest Island/ Wadjemup could best be described as an organically evolved landscape which has aspects of both a relict and a continuing landscape. As such its management will require careful consideration of these particular qualities. The plan embraces the many individual plans for conservation of precincts, buildings and landscapes over the past three decades. The vision is that 'Rottnest Island/Wadjemup will be widely recognised as a significant cultural landscape that is highly valued by the people of Western Australia. Future change will protect, enhance and celebrate its scientific, social, historic and aesthetic values and its unique island qualities' (RICLMP: ii).

The plan provides a series of heritage management principles that support these objectives: managing the A-Class Reserve as a cultural landscape; research and information sharing; building connections; the visitor experience, and shaping the future. Relevant constraints and opportunities are considered: governance, statutory and planning 
frameworks, Australian Standards and legislation for safety and universal access, visitors, commemoration and condition (RICLMP: 79ff). All works will be informed by an understanding of the specific heritage values attributed to the locality of the work as well as those of the Island as a whole. Cultural heritage values will continue to be included in strategic documents as a pivotal element of sustainability, while it is recognised that it is important to resolve potential or actual management conflicts that could impact heritage values and thus the long term sustainability of those values (RICLMP:86). Rottnest Island/Wadjemup has a high level of social value attached to both its use as a penal establishment and its subsequent use as a place for recreation. These values are often articulated as being polar opposites, and in many ways they are, however recreation on the Island is intrinsically linked through the tangible evidence of the Island's past use. The role of commemoration has the potential to more fully integrate these values in a way that can reconcile the past and lead to a more positive future (RICLMP:94).

In managing change, the cultural landscape should continue to be revealed through the protection of the geological and maritime sites, conservation of habitats, built form and associated settings, native vegetation enhancement, careful maintenance of cultural plantings and the protection of the coastal scenery and important view lines. Matters to be considered for managing change are set out in relation to the four identified zones of Rottnest Island/Wadjemup: marine, terrestrial, salt lakes, settlement. There is overlap as each of the zones is linked in the interwoven significance of the Island as a cultural landscape. A management plan is only effective if its provisions are implemented. The cultural landscape management plan has been adopted under the overarching Rottnest Island Management Plan (2014-19) and the Authority is committed to ensuring its effective implementation in accordance with the requirements of the Rottnest Island Authority Act.

\section{Conclusion}

The statement of significance of the cultural landscape sums up the range of cultural values of this small island which overwhelmingly has been a place of Aboriginal significance for at least 30,000 years. Since 2004, the Rottnest Island Authority has committed significant resources to improving public understanding of the importance of Aboriginal heritage and culture on the Island and the impact that its historical past still has today within Aboriginal communities. However, the significance of the Island to the whole of Western Australia as an Aboriginal penal establishment that housed prisoners as the colony expanded and as a deaths-in-custody site burial ground is not currently being recognised to the extent that these significant values warrant. The cultural heritage values of Rottnest Island/Wadjemup are demonstrated through a range of tangible and intangible attributes including geological formations, flora and fauna, Aboriginal heritage, buildings and structures and their settings, views, avenues, cultural deposits artefacts, records, memories and associations, along with uses and activities. Conservation must therefore consider all of these elements and attributes if their heritage values are to be retained in the long term as a cultural landscape. 


\section{Acknowledgements}

The author was a member of the team of specialist heritage practitioners, led by TPG Town Planning, Urban Design and Heritage under Nerida Moredoundt, who prepared the Cultural Landscape Management Plan for the Rottnest Island Authority in 2014.

\section{References}

Bates, D., 1992. The Legend of the Firestick: How Fire Came to the Bibbulmun, in P.J. Bridge (ed.), Aboriginal Perth: Bibbulmun Biographies and Legends, Hesperian Press, Victoria Park.

Dortch, C., Dortch, J., 2013. Archaeological evidence for early human presence in the western reaches of the Greater Swan Region, Western Australia, in Fremantle Studies No. 7, Journal of the Fremantle History Society, Fremantle.

Draper, Neale, 2015. Islands of the Dead? Prehistoric use of Kangaroo Island and other southern offshore islands and watercraft use by Aboriginal Australians, Quaternary International, 385, 229-242.

Gerritsen R., 2011. Selected Transcriptions, Translations and Collation of Information for a Textual Analysis Relating to Material Evidence from the Vergulde Draeck and the 68 Missing Crew and Passengers from that Vessel, Reportedly Found on the Coast of Western Australia in the Period 1656-1658, Batavia Online Publishing, Perth.

Green, N., 2011.Aboriginal Sentencing in Western Australia in the Late 19th Century with Reference to Rottnest Island Prison, in Bird, C., Webb, E. (eds.) 'Fire and Hearth' Forty Years On: Essays in Honour of Sylvia J. Hallam. Records of the Western Australian Museum, Supplement 79, Western Australian Museum, Perth.

Green, N., Moon, S., 1997. Far from Home: Aboriginal Prisoners of Rottnest Island, 1838-1931. University of Western Australia Press, Nedlands. Ker Wilson, B. (ed.), 1972. Tales told to Kabbarli, Crown Publishers Inc., New York.

Lennon, J., 2009. Port Arthur, Norfolk Island, New Caledonia: convict prison islands in the Antipodes, in William Logan and Kier Reeves (eds.), Places of Pain and Shame, dealing with 'difficult heritage', Routledge, Oxford, 165-181.

Lowenthal, D., 2003. Tragic traces on the Rhodian shore, Historic Environment, 17 (2), 3-7.

Playford, P., 1997. Geology and Hydrogeology of Rottnest Island, in H.L Vacher and T. Quinn (eds.), Geology and Hydrogeology of Carbonated Islands: Developments in Sedimentology, Elsevier Science B.V.

Register of the National Estate (RNE), ID 18825. Rottnest Island Raised Platforms and Notches, Digby Dr, Rottnest Island, WA, Australia, (viewed online March 2014, http://www.environment.gov.au)

Register of the National Estate (RNE), ID 18837. Rottnest Island and Marine Reserve, Rottnest Island, WA, Australia (viewed online March 2014, http://www.environment.gov.au)

Rottnest Island Authority, 2012. Rottnest Island - A guide to Aboriginal history on Wadjemup, RIA, Fremantle.

Rottnest Island Authority, 2012. Rottnest Island - A guide to the colonial buildings of the Thomson Bay settlement, RIA, Fremantle.

Rottnest Island Authority, undated. Birds of Rottnest Island (viewed online March 2014, http://www.rottnestisland.com/about/florafauna/birds) 
Rottnest Island Authority, 2012. Rottnest Island - It's our Heritage, RIA, Fremantle (RICLMP), Rottnest Island Cultural Landscape Management Plan, May 2015. http://ria.wa.gov.au/policy-and-reports/management-plans-and-legislation

Seddon G., 1983. The Rottnest Experience, in Bradshaw S D (ed.), Research on Rottnest Island, Journal of the Royal Society of Western Australia, Vol 66, 1 \& 2 .

Sheiner, R., 1986. Rottnest Island, in Geoffrey Dutton (ed.) The Book of Australian Islands, Macmillan, South Melbourne, 129-134.

Snell, T., 1998. The Artist's Rottnest, Fremantle Arts Centre Press.

UNESCO Intergovernmental Committee for the Protection of the World Cultural and Natural Heritage, 2008. Operational Guidelines for the Implementation of the World Heritage Convention.

Vizents, P., 2014. Artistic Responses to Rottnest, Unpublished report prepared for the Rottnest Island Authority.

Watson, E. J., 1939. Rottnest: Its Tragedy and its Glory, ed. Donald L. Watson, Perth. 